„Bohemistyka” 2019, nr 1, ISSN 1642-9893

Viktoria KNIAZKOVA

DOI: $10.14746 /$ bo.2019.1.7

St. Petersburg State University

\title{
Slovak Realia in the Czech Translation of the Novel The House of the Deaf Man by Peter Krištúfek in Contrast to its English Translation
}

Keywords: Krištúfek, Translation Studies, Slovak literature, identity, realia

\section{Abstract}

The article deals with two groups of realia in the Slovak novel by Peter Krištúfek (1973-2018). The first one are those concerning Slovak traditional culture, which are used in a form of theatrical scenery by the author. The second one are those connected with Slovak identity, as the writer understands it. The article offers the comparative analysis of the Slovak text with its translations into Czech and English. The conclusion is made about different translators' strategies according to the translation purpose and extralinguistic circumstances and the necessity of the Czech translations of Slovak fiction despite the unique closeness of these two Slavic languages.

The question whether translate Slovak literature into Czech has become actual in the recent years. This phenomenon is new for both Slovaks and Czechs that is why there are a lot of controversial questions connected with this issue. "Twenty books translated from Slovak were published last year in the Czech Republic. Is it really necessary to translate into the brotherly Czech?" - is the question put to the Slovak contemporary writers (Krištúfek 2013, trans1. V. Kniazkova).

Mira Nábělková in her study Slovenčina a čestina v kontakte [Slovak and Czech languages in contact] emphasizes the necessity of literary translations from Slovak into Czech, as the life in different states for the last almost thirty years resulted in difficulties in understanding of Slovak texts by the Czechs (though not visa versa) (Nábělková 2008, transl. V. Kniazkova). 
In their article Překladatelem snadno a rychle [To become a translator, easy and quickly] Machala and Kukučová list more than fifty translations of the works of fiction from Slovak into Czech for the period of 1993-2003. Besides that, they offer an overview of the present situation of Slovak-Czech literary translations, they say:

It is hard to find two languages that would be as close and accessible to each other as Czech and Slovak. However, it is precisely the clarity of Czech in Slovakia, and especially of Slovak in Bohemia and Moravia, that after the collapse of Czechoslovakia it has been repeatedly found to be decreasing, notably between youth and children. This unfavorable trend, along with the traditional, somewhat overlooked attitude of Czech readers to the offer and quality of Slovak literature, has prompted some publishers, literary creators and experts on both sides of the Morava River to further update their reflections on the need to translate Slovak books into Czech and to consider practical steps to help to disseminate Slovak literature in the Czech regions. We cannot overlook the almost only one direction of the whole process: despite the above mentioned decrease in mutual clarity among the users of the Czech and Slovak language (perhaps sometimes ostentatiously emphasized), reading of Czech fiction in the original in Slovakia between both intellectuals and ordinary readers is quite common (Machala, Kukučová 2010; transl. V. Kniazkova).

The co-author of the publication mentioned above, Kukučová, in her work Současné české překlady slovenské beletrie [Contemporary Czech translations of the Slovak fiction] gives a detailed analysis of the six modern Slovak texts and their Czech translations and comes to the conclusion of their mostly poor level and plenty of mistakes of different character (Kukučová 2010).

Slovak writer Peter Krištúfek (1973-2018) himself considered it had become important to offer Slovak literature to Czech audience through translation.

For a very long time, I was convinced that the translation of Slovak books into Czech is not necessary. Then I visited the bookstore Slovenska kniha in Prague, where nobody goes for weeks, and I found out that the Czechs almost do not know about the Slovak literature. It was amazing to me. The Czechs have forgotten Slovak - or perhaps for some reason they wanted to forget - and we should teach them again. But I'm afraid it will not be easy (Peter Krištúfek: Česi po slovensky zabudli 2013; transl. V. Kniazkova).
About translation of his own texts Peter Krištúfek said:

I try to get to know my translators personally, just as their work. [...] Consultation is very important for my texts, as I often use historical and local realia as well as various wordplays (Peter Krištúfek: Česi po slovensky zabudli 2013; transl. V. Kniazkova).

The latter ones are the object of our research in the most prominent, the biggest and the most translated Krištúfek's novel The House of the Deaf Man. The Slovak text was published in 2012 and there has been seven translations made so far: Amharic, Arabic, Bulgarian, Czech, Dutch, English, Polish (data by the year 2018). Czech and English translations of this novel and of the Slovak literary works in general represent two opposites in the most aspects of translation strategies. Czech is the language of the culturally, historically, geographically, economically closest nation and these translations are aimed at Czech audience only. English translations are made for the world audience in order to introduce not only Slovak literature, but Slovakia itself, as it is still not very much known in the world (Sampson 2004).

The House of the Deaf Man is a family saga, on one side, and literary treated Slovakia's history from the 1930s to the beginning of the $21^{\text {st }}$ century, on the other. The main hero of the novel Alfonz Trnovský, a general practitioner in the small (fictitious and very typical Slovak) town of Brežany survived four political regimes, the Jewish Question, the Second World War, the political trials of the $1950 \mathrm{~s}$, the secret police after 1968. The story is narrated by the doctor's son, Adam, who comes to say goodbye to the house which is going to be demolished. He tells the story of a father-son relationship, examining old things remaining in the house.

Postmodern character of the text is emphasized by skillfully weaving into the narrative extracts from documents, pieces of poetry, diaries, and even advertisements and medication prescribing information. The structure of the book is also polysemous. The chapters have their names according to the Francisco Goya paintings, the Black Series, now exhibited in the Museo del Prado after being removed from the walls of its original location, known as Quinta del Sordo (Deaf 
Man's Villa). Although the house had been named after the previous owner, who was deaf, Goya too was nearly deaf at the time as a result of an illness he had suffered before. The main hero of the book doctor Alfonz Trnovský ends his days in the family house also deaf and lonely. These Goya's paintings were his favourite ones and to get the clue to his father's life, his son, Adam, with his own son Bono undertake a journey to the Prado in Madrid.

The Krištúfek's book became the national bestseller as it depicts traditional Slovak life in a not traditional way. After its author tragic unexpected death in 2018 the book became a unique literary monument not only for Slovakia, but for the writer himself.

The House of the Deaf Man started from interest in family history, which I wanted to collect for myself, and I did not intend to publish it. It grew up and mixed with the stories of other people, and suddenly it came to me as a story of the difficult Slovak twentieth century and the complicated relationship of father and son. People often come to me and want to add something of their own family story to the novel. The interest in this book certainly results from the fact that many people are eager to find their roots. The reflection of that great national history is in the little stories of ordinary people who have had to overcome various regimes. But I did not expect such a powerful effect on the readers; it became clear only when the book came out (Peter Krištúfek o svojich knihách 2015; transl. V. Kniazkova). 2014.

The English translation of the Krištúfek's novel was published in

The husband-and-wife team completed the "notoriously difficult" translation of the 650-page novel in seven months. Inevitably, they said, some of Krištúfek's signature dead-pan humour was lost in translation, and small portions had to be added to clarify historical references unfamiliar to most English-speaking audience. Following a short reading from the finished English text, one listener commented that "for the first time, I have a bird's eye view of Slovak history that not many people have the faintest clue about." Another observed that despite tackling difficult themes, Krištúfek has kept a light-hearted tone by using a child's voice to narrate the war-torn tale (Jones 2014, p. 94)

The choice of the translators was always extremely important for Krištúfek:
I'm very demanding. In the case of the English translation of The House of the Deaf Man, The Centre for Information on Literature (LIC) helped me a lot and together we were looking for the most appropriate translator. My dream was Julia Sherwood, nee Kalinová, she lived in Slovakia for a long time, she knows the realia, on the other hand she is an experienced translator, lives in the English world, knows how it works. Her husband, Peter Sherwood, who also contributed to the translation, is an English native speaker, so they were translators dream team for me. Julia and her husband had to deal with lots of translation problems, starting with wordplays and ending with the various rhymes that I adore; they often had to create a completely new English equivalent. We exchanged a lot of emails and, thanks to their accuracy, there is the result that I am extremely satisfied with. Their English translation will be the gateway for other languages, such as Amharic (Peter Krištúfek o svojich knihách... 2015; transl. V. Kniazkova).

Speaking about the Czech version the author had entirely different requirements for a translator. As there is no obstacle to interpret any Slovak realia, wordplays or allusions into Czech, the translator's task was to avoid mere lexemes transformation, as it is very common in this pair of languages translations, but to create an adequate literary text using all the opportunities of the Czech language. That is why Krištúfek wanted it to be a writer to translate his text - Petra Hůlová became the author of the Czech version.

Realia in the Krištúfek's literary text can be divided into two main groups. The first group is represented by very vivid, though not very authentic, words and expressions for culture-specific material elements. The realia, depicting Slovak traditional culture are used not to add the authenticity, but quite the opposite, appear as theatrical scenery. Considering translations from Slovak into the world languages Krištúfek admits that ,everything is still complicated by the ambiguous or totally lacking promotion of Slovak culture abroad - because, on the one hand, Slovakia almost does not finance it, unlike, for example, the Czech Republic, Poland and Hungary and, moreover, there are often people in charge, who do not care or do not understand what they are doing. The result is either complete ignorance of Slovakia or the promotion of culture through valašky, krpce and šúpolienky, which I consider to be absolutely despicable" (Peter Krištúfek o svojich knihách... 2015; transl. V. Kniazkova). 
These ideas are fully represented in the text of the novel:

V ten deň sa mal konat' Salón, takže si pani Natália nakoniec popoludní predsa len požičala personál z grófskeho kaštiel’a. Kuchára a dve služky. Konal sa zvyčajne v jej milovanej Slovenskej izbe, kde nechýbali valašky, vyrezávaný mal'ovaný nábytok na mieru, obrazy, sadrový bača s ovčiarskym psom a typický brežiansky kroj (DH, p. 58).

V ten den se měl konat Salón, takže si pani Natália odpoledne nakonec půjčila personál z hraběcího zámku. Kuchaře a dvě služky. Salón se obvykle konal v její milované Slovenské jizbě, kde nechyběly valašky, na míru vyřezávaný malovaný nábytek, obrazy, sádrový bača s ovčáckým psem a typický brežanský kroj (DHCZ, p. 91).

As this was the day of Natalia's regular salon, she had no choice but to borrow domestics from the manor of the local count. A cook and two maids. She usually held her salon in her beloved Slovak Room, replete with shepherds' hatchets, custom-carved folk-style wooden furniture, a plaster shepherd with a sheepdog and an example of the local costume (HDM, p. 59).

As it can be observed in the above-stated quotations, the translators' strategies differ in a way they treat the Slovak realia. Lexeme kaštiel' refers to one of the types of aristocracy (mainly Hungarians) dwelling in Slovakia, not having their equivalent in Czechia. Treating the phrase slovenská izba as a name, the Czech translator Petra Hůlová has not merely changed the Slovak word izba into the Czech equivalent pokoj. She offered instead a loanword jizba, using transcription method (Vlakhov, Florin 1980, p. 87) and changing the word according to the Czech phonetic rules, avoiding the initial vowel and using prosthetic consonant $j$. Thanks to this compensation the translator was able to show that all these pieces of traditional culture served only as decoration. All other realia the translator had to leave in the Czech text, because they are familiar to Czech readers as specific items of Slovak traditional culture.

The English translators used description method (Vlakhov, Florin 1980, p. 91), translating valašky, vyrezávaný mal'ovaný nábytok and kroj, and generalization method (Vlakhov, Florin 1980, p. 90) translating bača just as shepherd. All these realia items are used to show the artificiality of the Slovak traditional national culture, though loved by people, but not constituting their real gist.

A motif of scenery and performance is very often used in the novel, especially in the situations depicting family relationships and meetings. The same symbolic meaning of decoration have the names of traditional Slovak meals and food.

Otec sa neúnavne snažil dodržiavat' rodinné rituály, alebo aspoň to, čo si pod nimi predstavoval. V nedel'u sa patrilo usporiadat' pravý nedel'ný obed. Nedel'ný obed v klasickom duchu, napríklad okolo roku 1938, mal svoje ustálené pravidlá [...] Ako hlavné jedlo sa podávalo vyprážané kura so zemiakmi [...] s kapustou, knedl'ou alebo lokšami (DH, p. 60).

Otec sa neúnavně snažil dodržovat rodinné rituály, nebo tedy alespoň to, co si pod nimi představoval. V neděli se slušelo uspořádat' pravý nedělní oběd. Nedělní oběd v tradičním duchu, např́klad okolo roku 1938, měl svoje ustálená pravidla [...] Jako hlavní jídlo se podávalo smažané kuře s brambory [...] se zelím, knedlíkem nebo lokšemi (DHCZ, pp. 94-95).

Father never tired of trying to keep up family rituals, with everything he thought that entailed. On Sundays there had to be a proper Sunday lunch. A classic Sunday lunch say in 1938, followed certain fixed rules [...] The main course was fried chicken with potatoes [...] served with cabbage, dumplings or lokše, potatoe flatbread fried in goose fat (HDM, pp. 61-62)

Describing the family traditions, the narrator emphasizes their artificiality and theatrical character like a very good prepared performance. Meals realia, knedl'a and lokše, have their well-known equivalents in Czech, but in English the first one is translated by generalization (dumpling), the second one by borrowing followed by description (lokše, potatoe flatbread fried in goose fat) with a borrowed word written in italics. The same method is used by the English translators every time a realia plays a role of the scenery, as in the following examples:

Veselilo sa a na zasneženom chodníku v záhrade sa podávalo hriatô, zvané aj krampampul'a. Rovnako hnusne chutilo s jedným i druhým názvom a všetci ho pili tak trochu ako za trest (DH, p. 75). 
Slavilo se a na zasněženém chodníku v zahradě se podával nápoj hriatô, nazývaný též krampampul'a. Chutnal př́šerně pod jedním i druhým názvem a všichni ho pili tak trochu jako za trest (DHCZ, p. 118)

Everyone was jolly and people standing on the garden path covered with snow were swigging hriato, the hot toddy laced with hot melted lard. Also known as $\mathrm{kram}$ pampul'a, it tasted equally disgusting whatever you called it and drinking it was generally concidered something of a punishment (HDM, p. 80).

Besides the borrowed Slovak lexemes, Czech translator used a hypernym to clarify the name of a not very familiar Slovak traditional drink for Czech readers.

If a realia is used in its common way, not as a part of scenery, but as a usual everyday item, it is translated into both, Czech and English without borrowing the Slovak word. Compare the word kapustnica in two different situations:

Až neskôr som zistil, že napríklad kapustnica, ako ju varí iba on (pretože tak to hovoril) vlastne nie je žiaden originálny recept, presne tak ju totiž robia všetci v našom kraji (DH, p. 73)

Až později jsem zjistil, že například zelňačka, jak ji vaří jen on (tak to říkal) vlastně žádný originální recept není, přesně tak ji totiž dělají v našem kraji všichni (DHCZ, p. 73).

Only later did I discover that, for example, what he claimed as his own cabbage soup recipe wasn't really unique and that everyone in our part of the country made it exactly the same way (HDM, p. 77).

Tina sa stala regulérnou britskou občankou. Túžba po domove ju však prenasledovala pravidelne. Neprekvapilo ma, že Slovensko pre ňu nepredstavujú ani bryndzové halušky (ktoré, mimochodom, neznášala) ani kapustnica (pokial' mohla, vyhýbala sa jej). Celé roky si namiesto toho nechávala posielat' poštou Kávenky. Vravela, že to je pravá chut' domova. Ked' si odhryzla, oči sa jej zaliali slzami, tak mi to aspoň tvrdila. Teatrálnost' zdedila po našej mame (DH, p. 381).

Tina se stala regulérní britskou občankou. Nepřestala ji ale pronaslédovat touha po domově. Nepřekvapilo mě, že Slovensko pro ni nebyly ani bryndzové halušky (které, mimochodem, nesnášela), ani kapustnica (pokud mohla, tak se jí vyhnula). Celé léta si místo toho nechala posílat poštou kávenky. Říkala, že to je pravá chut' domova. Když se do nich zakousla, oči sa jí zalily slzami, tak mi to alespoň tvrdila. Teatrálnost zdědila po naší matce (DHCZ, p. 574).
Although Tina had become a fully-fledged British citizen she still felt homesick. It was no surprise that it wasn't the stereotypical national dishes such as bryndzové halušky, the popato gnocchi with ewe's cheese, which she had always hated or kapustnica, the sauerkraut soup she had always tried to avoid, that symbolised Slovakia to her. Instead, we had to supply her for years with Horalky wafers. She claimed their chocolate and peanut filling epitomized the genuine taste of home. Tears welled up in her eyes whenever she took a bite, at least so she claimed. She had inherited Mother's histrionic streak (HDM, p. 436).

There are also two more realia in the latter quotation: bryndzové halušky and Kávenky. The first one is reproduced by borrowing the Slovak lexeme in both translations (in English with putting it in italics and adding a description). The second one is replaced in English by another similar Slovak product (perhaps, more typical in the translators' opinion) with addition of hypernym wafers.

The last sentence in the above mentioned quotation contains the clue to this aspect of Krištúfek's literary idea. In the beginning of the paragraph the narrator expresses the author's idea, that halušky and kapustnica, being typical Slovak dishes, do not symbolize Slovakia. It is seemingly another Slovak dish Kávenky that can overtake this role, but not: this was just the author's irony. The heroine's love for these wafers is only a theatrical performance. The motif of the performance and play is typical for the novel and quite frequent in other Krištúfek's literary works, as the writer himself was a screenwriter and film director (he graduated from the Film and Television Faculty at Academy of Performing Arts Bratislava) and so is the narrator of The House of the Deaf Man. Some scenes of the novel are described like in a play script (e.g. the scene with a bird entering the family Sunday lunch (DH, p. 63; DHCZ, pp. 99-100; HDM, pp. 65-66) is written in the tradition of the Gogol's play The Government Inspector). Some have direct references to the film or theatre performance:

Strih. Na scénu prichádza druhý muž - starý otec môjho otca [...] (DH, p. 9). Střih. Na scénu přichází druhý muž - dědeček mého otce [...] (DHCZ, p. 19).

Cut. Enter another man - my father's grandfather [...] (HDM, p. 4). 
Rodinné oslavy a nedel'né obedy už nikoho nebavili. Zostali len zle nacvičeným divadelným predstavením, $\mathrm{v}$ ktorom herci pravidelne vypadávali zo svojich úloh (DH, p. 368).

Rodinné oslavy a nedělní obědy už nikoho nebavily. Stala se z nich jen špatně nacvičená divadelní predstavení s herci, co pravidelně vypadávali ze svých rolí (DHCZ, p. 554).

All the joy had gone out of our family gatherings and Sunday lunches. They were reduced to an ill-rehearsed theatre production whose actors regularly forgot their lines (HDM, p. 421).

The second group of realia is more latent, they are not always realia in traditional understanding of this term (Vlakhov, Florin 1980, p. 10; Fernández Guerra 2012, p. 2), but they reflect actual writer's vision of the Slovak real life. Krištúfek is very interested in the Slovak identity question, a burning issue in the Slovak literature after Slovakia became a sovereign state in 1993. To study this problem, the writer reproduces the most significant events of the Slovak history over the last hundred years through a story of a family in an invented town of Brežany.

The House of the Deaf Man is not a documentary nor a historical novel in the proper meaning of the term. I needed freedom for the narrative. Brežany, however, carries all the signs and historical phases of any western Slovak town - those absurd, even those painful"

- says the author (Balogh 2013).

The Slovak inferiority complex which is reflected in the most Slovak contemporary writings is present in the Krištúfek's reasoning about small sizes of the country, towns and nation:

L’udia zbožňujú situácie ako z filmu, najmä v malom meste, plnom malých l'udí, ktorí malými zostali, aj ked' mesto narástlo a napuchlo, rozlialo sa do okolia a dostalo označenie „okresné”, a aj tak zostalo navždy malým mestom. Zakliatym, hrdým na svoju obrovskú malost’ a na svoje malé spôsoby (DH, p. 52).

Lidé zbožňují situáce jako z filmu, zvlášt’ v malém městě, plném malých lidí, kteř́ zůstali malými, i když se město zvětšilo a napuchlo, rozlilo se do okolí a dostalo označení „okresní”, ale i tak navěky zůstalo malým městem. Zakletým, hrdým na svou nesmírnou malost a svoje malé způsoby (DHCZ, p. 81).
People like things that remind them of film scenes, particularly in a small town inhabited by small people who have remained small even after the town has expanded, spilling into its environs and acquiring the designation of a "district" town, but remaining a small town none the less. A town under a spell, proud of its enormous smallness and small manners (HDM, p. 52)

This paragraph is repeated in the novel several times. This is one of the favourite Krištúfek's techniques which makes the same idea stated in different contexts sound differently. Another epitheton used to describe Slovak nation is holubičí národ [387] (národ holubiči [583] in Czech, and more explicit nation of peace-loving doves [443] in English). This very phrase is frequently used by other Slovak writers, e.g. in the novel Die beste aller Welten [The Best of All Worlds] ${ }^{1}$ by a Swiss-Slovak writer Irena Brežná ${ }^{2}$.

Another common idea of both novels, the one by Brežná and Krištúfek's The House of the Deaf Man, is loss of faith in Slovakia during the Communist era. Slovakia, being a highly religious country, even under the communist system tried to keep its church and live according to religious traditions. However, because of communist propaganda the majority of Slovaks, especially young ones, had to accept both ideological systems. This mixture of thinking is expressed by realia in the novel:

Aj súdruh Kristus to tak predsa robil! (DH, p. 27).

Dělal to tak přece i soudruh Kristus! (DHCZ, p. 44)

Didn't comrade Jesus want to do the same? (HDM, p. 23).

Pamätám sa, že ma raz ako šestročného hrešila, ked' som jej opisoval, kde som stretol strýka Oskara slovami: „Tam za mestom, kde je Imri, čo ukazuje smer.” Áno, križovali sa tam cesty, jedna ruka mierila na západ a druhá na východ, aby pútnici

1 Die beste aller Welten (2008) was written in German and translated into Slovak from the author's manuscript by Jana Cviková under the title Na slepačich krídlach (2007).

${ }^{2}$ See more on concept of nation of doves in Hrdličková 2012, p. 130. 
vedeli kadial' sa vybrat' do Brežian. A ten pán mal nad hlavou napísané svoje meno.

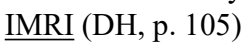

Pamatuji si, že mě jako šestiletého hubovala, když jsem jí popisoval, kde jsem potkal strýčka Oskara: „Tam za městem, kde je Imri, co ukazuje směr.” Křižovaly sa tam totiž cesty, jedna ruka mírila na západ a druhá na východ, aby poutníci věděli, kudy do Brežan. A ten pán měl nad hlavou napsáno své jméno. IMRI (DHCZ, p. 164).

I remember being six years old and Grandma telling me off because of the way I described a place I'd been to with Uncle Oskar: "You know this place at the end of town, there is this man, Imri and he's showing the way." What I had in mind was the crossroads with a statue of a man whose one hand pointed west and another east to help pilgrims find their way to Brežany. The man's name, written above his head, was IMRI (HDM, p. 115).

Brežná's main heroine, a Slovak girl in 1950s, is also thinking of two oppotunities in a difficult situation: whether to pray to Jesus Christ or to write to the comrade president (Kniazkova 2017b).

The child narrator, which is another common feature of both novels, gives the opportunity to show the history from another point of view: the war and the tragic events of the communist period are perceived more as a game. This is also the fact, that brings popular Slovak children's games into Krištúfek's attention:

A ako sa pomaly na ceste predo mnou vynára náš starý dom, v hlave mi ako ozvena znie detský pokrik Čik-čik, domček! Volali sme tak, ked' sme konečne dobehli do bezpečia. Bolo to zaklínadlo. Neúčinné zaklínadlo (DH, p. 15)

A jak se pomalu na cestě přede mnou vynořuje náš starý dům, v hlavě mi jako ozvěna zní dětský pokřik čik-čik, domeček! Tohle jsme volali, kdy jsme konečně doběhli do bezpečí. Bylo to zaklínadlo. Neúčinné zaklínadlo (DHCZ, p. 28).

As our old house gradually materializes in front of me, I hear the echo of us children shouting čik-čik, domček!, Home, home, our very own! We used to chant this when we finally reached the haven of our house. It was our private spell. A spell that didn't work (HDM, p. 9).

Becoming older, Adam, the narrator, repeats this rhyme every time he returns to the house:

V hlave mi znelo zaklínadlo Čik-čik, domček! ako zvyčajne, ked’ som sa vrátil (DH, p. 431).

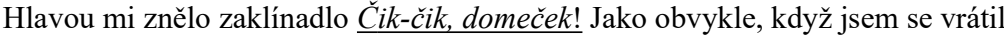
(DHCZ, p. 649).

Our childhood rhyme, $\underline{c} i k$-čik, domček!, rang in my ears as it did every time I returned (HDM, p. 494).

This popular Slovak children rhyme was indeed made by Krištúfek a kind of spell he uses to refer to the bond between his heroes and the family house. The idea of safety of the home which should have this rhyme symbolized turned out to be an illusion, as the house did not save the heroes from ending their lifes splitted up and lonely. In both quotations, this Slovak realia is used in the context of the house description. Czech translator uses the method of literal translation with emphasizing the realia with italics, which is quite enough for understanding the idea. English translators use the borrowing in italics followed by translators' own English equivalent rhyme. The next time we find the borrowing without any translation or explanation.

Another Slovak children game is used by Krištúfek. It is a game, where the players should write a forname, a town, an animal and a thing, all beginning with the same letter. The name of the game is incorporated into the wordplay:

Puškár odtancoval a, ako mal vo zvyku, recitoval si s úsmevom popod nos slovnú hračku, čo práve vymyslel: „Menu. Menu... Menu, mestu, zvieru, vuc” (DH, p. 68).

Puškár odtančil a, jak měl ve zvyku, s úsměvem si pod vousy recitoval slovní hříčku, kterou právě vymyslel: „Menu. Ménu... Ménu, městu, zviŕu, vuc!” (DHCZ, p. 107).

Puškár skipped away, smiling and reeling off a stream of similar-sounding words under his breath, as was his habit: "Menu. Menuet... Menuet, minuet, minuetto, just a minuetto!"

There is the same Czech game sounding jméno město zvíre věc, so the Czech translator left the same wordplay slightly modified according to the Czech language rules. The English version contains functional equivalent with a new wordplay without any allusions to the children's game. 
One of the main ideas of the novel is the search for the answer to the Slovak identity question. As many of his contemporaries, Krištúfek considers question in two main contexts: European and Slavic ones. He sees some Slovak features as common for all Slavic nations:

[...] väčšinou starí mastní súdruhovia, tekuté tváre, aké sa vyskytujú vo vyššom veku len u slovanských národov (videl som ich v Pol'sku, v Rusku a ešte aj v Juhoslávii) [...] (DH, p. 400).

[...] většinou staří mastní soudruzi, tekuté obličeje, jaké sa vyskytujú vo vyšším věku jen u příslušníků slovanských národů (viděl jsem je v Polsku, Rusku a taky v Juhoslávii) [...] (DHCZ, p. 603).

[...] mainly fat old comrades with typically sagging Slavic physiognomies (I've seen faces like these in Poland, Russia as well as in Yugoslavia) [...] (HDM, p. 458).

However, Krištúfek sees the Slovakia's way as being a Central European country more, than Slavic one. He even puts Brežany in one line with European capitals:

Berlín je modrý, Paríž zelený, Viedeň oranžová, Brežany trochu do hneda (DH, p. 220)

Berlín je modrý, Pařiž zelená, Vídeň oranžová, Brežany tak trochu do hněda (DHCZ, p. 336).

For me Berlin is blue, Paris is green, Vienna orange and Brežany is tinged with brown (HDM, p. 249).

Telling about traditions or situation in Slovakia, the author refers to it as Europe or Central Europe, much more than just the country.

Najmä v strednej Európe (DH, p. 33).

Zvlášt’ ve střední Evropě (DHCZ, p. 30).

This is especially true in Central Europe (HDM, p. 30).

This corresponds with another Slovak contemporary writer Pavel Vilikovsky's ideas on the Slovak national identity as a part of Central European mentality expressed in his novel Ever Green is... (1989), but probably most fully outlined in his short-story Everything I know about Central Europeanism (With a Little Friendly Help from Olomouc and Camus) (1996) ${ }^{3}$.

Krištúfek, describing Russian soldiers during the war, always puts them in contrast with people in Europe:

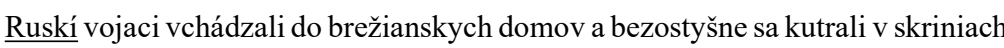
a zásuvkách ' 85 vzali zo stola Petrovo rádio, naše jediné spojivo s vonkajším svetom. Otec si to všimol až potom, ako odišli. Krútil hlavou: „Títo l’udia prvý raz v živote vidia civilizovanú Európu. Asi je to pre nich šok. Musíme to pochopit”'(DH, p. 166).

Ruští vojáci navštěvovali brežanské domácnosti a bezostyšně se hrabali v skřiních a zásuvkách ' 85 vzali ze stolu Petrovo rádio, naše jediné spojení $\mathrm{s}$ vnějším světem. Otec si toho všiml až potom, co odešli. Kroutil hlavou: „Ti lidé vidí poprvé civilizovanou Evropu a asi je to pro ně šok. Musíme to pochopit" (DHCZ, pp. 255-256).

The Soviet soldiers went in and out of Brežany's homes at will, shamelessly rummaging through wardrobes and drawers. [ . ] the Russians swiped Peter's radio off the table, cutting off our only connection to the outside world. Father didn't notice until they were gone. He shook his head: "This is the first time these people have seen civilized Europe. It must have come as a shock to them. We have to try and understand them" (HDM, pp. 185-186).

Jewish line is very strong in the novel: the narrator's mother is a Jew, the text of the novel is full of lexemes in Yiddish given in italics (e.g. zejde Blau, bobe Sára), there are a lot of Jewish traditions depicted in the novel. Krištúfek considers Jewish culture as a very important part of the Slovak history and present life. In one of his last interviews, Krištúfek explains his vision:

I'm interested in the Jewish theme because it is Central European and a person living in this area must assume a stance on this issue. I like reading Jewish authors they have another angle of view, they think differenly (Sedláková, Dvořáková 2012; transl. V. Kniazkova).

Krištúfek's description of the narrator's son origin comes out to be a quintessence of the author's ideas on the Slovak identity question:

\footnotetext{
${ }^{3}$ See more on this question in: Sabatos 2003, Kniazkova 2017a.
} 
V konečnom dôsledku je môj syn Bony naozaj echt pravý Slovák, pretože v jeho tele koluje česká, mad'arská, nemecká, pol’ská, židovská a nakoniec aj slovenská krv, tak to má byt'. Stredoeurópske cuvée (DH, p. 34).

V konečném důsledku je můj syn Bony skutečné echt pravý Slovák, protože v jeho těle koluje česká, mad’arská, německá, polská, židovská a koneckonců i slovenská krev, tak to má být. Středoevropské cuvée (DHCZ, p. 54).

Ultimately that makes my son Bony an echt Slovak because in his veins there flows Czech, Hungarian, German, Polish, Jewish and, not least, also Slovak blood. A proper Central European cuvée (HDM, p. 31).

In the Slovak text two words are emphasized by the writer in italics (echt and cuvée). Both of them are of the clear foreign origin, but used in Slovak, as well as in Czech, though the degree of their assimilation in the languages is different. Using familiar, but foreign loanwords in combination with Slovak nation characterization gives the linguistic proof to the expressed literary idea.

The article Prekladat', alebo neprekladat? Niekol'ko postrehov k súčasným vzt’ahom slovenskej a českej literatúry [To translate or not to translate? Several insights into current relationships between Slovak and Czech literature] by Radoslav Passia proves the necessity of the translation from Slovak into Czech. The author of the article emphasizes that literary translation should be more than just a linguistic interpretation, it should not lose the values contained in the original work and should provide the reader with a full reading experience (Passia 2008).

The analysis of Krištúfek's text and its translations gives an opportunity to claim that literary translation from Slovak into Czech does not only provide convenience and ease for Czech audience to read in their native language (although they can understand Slovak quite well), but it gives them an absolutely different literary experience. In contrast with the English translation, which has mostly familiarization function, the Czech one brings new ideas into old knowledge. The Slovak realia in the English text are mostly reproduced with the method of borrowing followed by explanation and serve as exotisms. For a Czech reader these realia are familiar, though if read in Slovak, the whole text of the novel would have been perceived as realia. That is why Slovak borrowings in the Czech text reflect the main author's intention to depict the Slovak life how it seems on the surface and what is its real gist.

\section{Source shortcuts}

DH Peter Krištúfek, Dom hluchého, Marenčin PT, 2012.

DHCZ Peter Krištúfek, Dům hluchého, trans. P. Hůlová, Větrné mlýny, 2016.

HDM Peter Krištúfek, The House of the Deaf Man, trans. J. Sherwood, P. Sherwood, Parthian, Great Britain, 2014.

\section{References}

B a 1 o g h A., 2013, Peter Krištúfek o Dome hluchého: V Brežanoch sa to stalo presne takto. Online: https://kultura sme.sk/c/6939725/peter-kristufek-o-domehlucheho-v-brezanoch-sa-to-stalo-presne-takto.html\#ixzz5SIFbwyHE [18.09.2013].

Fernández Guerra A., 2012, Translating culture: problems, strategies and practical realities, „Art and Subversion” 3, No. 1, 12/2012 - LT.1.

H r d li č k o vá J., 2012, Der Slowakidiskurs bei Irena Brežná und Zdenka Becker, „Brünner Beiträge zur Germatistik und Nordistik”26, No 1-2, pp. 127-136.

Jo n e s V., 2014, The House of the Deaf Man: An English Debut, „Savage Journal”, 18.11. Online: http://www.savageonline.co.uk/our-london/the-house-of-a-deaf-man-an -english-debut.

Kn i a z o v a V.S., 2017a, Search for Identity in the Works of the Slovak Writer P. Vilikovskii (by the Material of the Story "All I Know about Central Europeanism”), „Filologicheskiye nauki. Voprosy teorii i praktiki” [Tambov: Gramota], No 3, Ch. 2, pp. 31-34. Online: http://scjournal.ru/articles/ issn_1997-2911_2017_3-2_07.pdf.

K n i a zkova V.S. 2017b, Enciphered Toponyms in the German Novel by I. Brezna "Die beste aller Welten” and its Translation into the Slovak Language, ,Filologicheskiye nauki. Voprosy teorii i praktiki” [Tambov: Gramota]. No 10(76): v 3 ch. Ch. 2., pp. 23-26. Online: http://scjournal.ru/articles/ issn 1997-2911 2017 10-2 05.pdf.

Ku kučová S., 2009, Současné české překlady slovenské beletrie. Bakalářská diplomová práce, Olomouc.

M a c ha la L., K u k u č o vá S., 2010, Překladatelem snadno a rychle. K českým prekladům současné slovenské beletrie, „Listy. Dvouměsíčník pro kulturu 
a dialog”, No 1. Online: http://www.listy.cz/archiv.php?cislo=101\&clanek $=011012$.

N á b ěl k o vá M., 2008, Slovenčina a čeština v kontakte, Bratislava-Praha.

P a s s i a R., 2008, Prekladat', alebo neprekladat? Niekol'ko postrehov k súčasným vzt'ahom slovenskej a českej literatúry. „Dokořán” 12, č. 47, s. 22-24.

Peter Krištúfek o svojich knihách, ich prekladoch a všetkom, čo nás zaujímalo, 2015.

Online: http://www.lita.sk/magazin/rozhovor-peter-kristufek [16.04.2015].

Peter Krištúfek: Česi po slovensky zabudli, 2013, „Kultúra. Pravda”, 22.05. Online: https://kultura.pravda.sk/kniha/clanok/281313-peter-kristufek-cesi-po-slo vensky-zabudli.

S a b a t o s Ch., 2003, Czechs, Sex, Spies and Torture: Slovak Identity as Translation in Vilikovský's Ever Green is... "Comparative Literature Studies" 40 [The Pennsylvania State University, University Park, PA.], No. 2, pp. 173-192.

S a m p s o n F., 2004, Publikovanie prekladovej poézie vo Vel'kej Británii: slovenská skúsenost', „Slovo a svet” [Bratislava], p. 139.

S e d lá k o vá K., D v o řá k o vá H., 2012, Peter Krištúfek: Kto čita, prežije viac životov. Online: https://feminity.zoznam.sk/c/876073/peter-kristufek-kto-cita-prezije-viac-zivotov\#ixzz5P6MzAiNz.

V l a k hov S., F lo ri n S., 1980, Neperovodimoe v perevode, Moskva. 